\title{
The Input-output Analysis on Science and Technology Project in Shaoxing during the 12th Five-Year Plan Period
}

\author{
Shouyu Chen \\ Zhejiang Yuexiu University of Foreign Languages, Shaoxing, P.R.China \\ chenshyu@zju.edu.cn
}

Keywords: Input-output analysis; Science and technology project; 12th five-year plan; Shaoxing city; Government

\begin{abstract}
The science and technology projects play an important role in promoting the development and progress of science and technology, which has been widely recognized. This paper mainly discusses the situation of science and technology project in Shaoxing city during the 12th Five-Year Plan period by using input-output analysis. First of all, the main reasons for the failure of the project are Lack of project investment funds, Lack of the economic benefits and Lack of the technical indicators. Secondly, the paper introduces the type of project, consisting of three major types of "first-level plan project" and 11 sub-categories of "second-level plan project". Science and technology projects mainly distributed in key industrial projects, public service application technology projects, institute and university cooperation projects. Further, the average proportion of government financial aid in the project investment is $12.73 \%$ and the effect of financial capital promoting the project actual investment is obvious. Finally, these projects to achieve higher performance mainly reflected in the following aspects: the qualified products or software system produced, the research paper published, the number of invention patents or utility model patent authorized and the economic benefit of the project.
\end{abstract}

\section{Introduction}

During the 12th Five-Year Plan period, Shaoxing city has 602 science and technology projects to apply for completion acceptance, of which 588 projects are approved, accounting for $97.67 \%$ of all application projects. Other 14 projects are not approved, accounting for $2.33 \%$ of all application projects. There are the several main reasons for failure to be approved (Table 1). Firstly, lack of project investment funds. Secondly, the economic benefits, such as sales, profits and taxes, which are produced by the project, cannot reach the requirements of the contract. Finally, the project planned technical indicators did not complete. The following analysis will be based on only 588 approved acceptance projects, excluding these unqualified items.

Table 1 Reasons for unapproved projects

\begin{tabular}{|c|c|c|}
\hline Reason & Number of Items & Percent \\
\hline Lack of project investment funds & 6 & $42.9 \%$ \\
\hline Lack of the economic benefits & 5 & $35.7 \%$ \\
\hline Lack of the technical indicators & 3 & $21.4 \%$ \\
\hline Total & 14 & $100.0 \%$ \\
\hline
\end{tabular}

\section{The Distribution of Project Types}

The science and technology projects have involved three major types of "first-level plan project" and 11 sub-categories of "second-level plan project". According to Table 2, from the second-level plan project, science and technology projects mainly distributed in key industrial projects (176 items, 29.93\%), public service application technology projects (96 items, 16.33\%), institute and university cooperation projects ( 87 items, $14.80 \%$ ), and the total proportion of the above three type 
projects is up to $61 \%$. Key agriculture projects, key social development projects and agricultural science and technology achievement transformation projects are less, accounted for only $24.82 \%$ of the all of projects.

Table 2 The distribution of project types

\begin{tabular}{|l|l|c|c|}
\hline \multicolumn{1}{|c|}{$\begin{array}{c}\text { First-level Plan } \\
\text { Project }\end{array}$} & \multicolumn{1}{|c|}{ Second-level Plan Project } & $\begin{array}{c}\text { Number } \\
\text { of Items }\end{array}$ & Percent \\
\hline \multirow{4}{*}{$\begin{array}{l}\text { Science and } \\
\text { Technology Project } \\
\text { (A) }\end{array}$} & Major Industrial Projects (A1) & 22 & $3.74 \%$ \\
\cline { 2 - 4 } & Key Industrial Projects (A2) & 176 & $29.93 \%$ \\
\cline { 2 - 4 } & Key Agriculture Projects (A3) & 64 & $10.88 \%$ \\
\cline { 2 - 4 } & Key Social Development Projects (A4) & 45 & $7.65 \%$ \\
\cline { 2 - 4 } & $\begin{array}{l}\text { General Agricultural Projects (A5) } \\
\text { General Social Development Projects } \\
\text { (A6) }\end{array}$ & 27 & $4.53 \%$ \\
\hline \multirow{3}{*}{$\begin{array}{l}\text { Science and } \\
\text { Technology } \\
\begin{array}{l}\text { Industrialization and } \\
\text { Special Plan (B) }\end{array}\end{array}$} & $\begin{array}{l}\text { Popularized Programs of science and } \\
\text { technology achievement (B1) }\end{array}$ & 4 & $0.68 \%$ \\
\cline { 2 - 4 } $\begin{array}{l}\text { Institute and University Cooperation } \\
\text { Projects (B2) }\end{array}$ & $\begin{array}{l}\text { Agricultural science and technology } \\
\text { achievement transformation projects (B3) }\end{array}$ & 37 & $14.80 \%$ \\
\cline { 2 - 4 } & $\begin{array}{l}\text { Public Service Application Technology } \\
\text { Projects (B4) }\end{array}$ & 96 & $16.33 \%$ \\
\hline $\begin{array}{l}\text { Innovation Conditions } \\
\text { and Environmental } \\
\text { Construction Plan (C) }\end{array}$ & $\begin{array}{l}\text { Public Platform, Key Laboratory } \\
\text { Construction (C) }\end{array}$ & 21 & $3.57 \%$ \\
\hline \multicolumn{1}{|c|}{ Total } & 589 & $100.00 \%$ \\
\hline
\end{tabular}

\section{Project Investment}

According to Table 3, during the 12th Five-Year Plan period, the science and technology projects are invested 970.067 million yuan including government financial subsidies 123.465 million yuan, accounting for $12.73 \%$ of the total investment. The effect of financial capital promoting the project actual investment is obvious, especially in the field of key industrial projects, on average, each project financial assistance accounted for only $6.8 \%$ of the total investment in key industrial projects.

Table 3 Project investment

\begin{tabular}{|c|c|c|c|c|c|}
\hline \multirow[b]{2}{*}{ Item Type } & \multicolumn{2}{|c|}{ Government Fiscal Subsidy } & \multicolumn{2}{|c|}{ Actual Project Investment } & \multirow{2}{*}{$\begin{array}{l}\text { Average } \\
\text { Proportion of } \\
\text { Fiscal Subsidy } \\
\text { for Each Item }\end{array}$} \\
\hline & $\begin{array}{c}\text { Total Fiscal } \\
\text { Subsidy }\end{array}$ & $\begin{array}{l}\text { Average } \\
\text { Fiscal } \\
\text { Subsidy }\end{array}$ & $\begin{array}{l}\text { Total Actual } \\
\text { Investment }\end{array}$ & $\begin{array}{c}\text { Average } \\
\text { Actual } \\
\text { Investment }\end{array}$ & \\
\hline A1 & 1393.0 & 63.3 & 8099.9 & 368.2 & $17.2 \%$ \\
\hline $\mathrm{A} 2$ & 3315.2 & 18.8 & 49031.0 & 278.6 & $6.8 \%$ \\
\hline A3 & 860.7 & 13.4 & 3069.4 & 48.0 & $28.0 \%$ \\
\hline A4 & 407.4 & 9.1 & 2893.9 & 64.3 & $14.1 \%$ \\
\hline A5 & 43.0 & 4.8 & 425.4 & 47.3 & $10.1 \%$ \\
\hline A6 & 63.7 & 2.4 & 206.3 & 7.6 & $30.9 \%$ \\
\hline B1 & 50.0 & 12.5 & 174.0 & 43.5 & $28.7 \%$ \\
\hline B2 & 3208.0 & 37.3 & 24059.5 & 276.5 & $13.5 \%$ \\
\hline B3 & 596.7 & 16.1 & 2007.2 & 54.2 & $29.7 \%$ \\
\hline B4 & 728.1 & 7.6 & 1566.5 & 16.3 & $46.5 \%$ \\
\hline $\mathrm{C}$ & 1680.6 & 80.0 & 5473.7 & 260.7 & $30.7 \%$ \\
\hline Total & 12346.5 & & 97006.7 & & \\
\hline
\end{tabular}


Unit: 0.01 Million Yuan

Public platform, major industrial, key industrial, institute and university cooperation projects no matter in the financial aid or total investment are relatively large, average fiscal subsidies is more than 0.3 million yuan, and the average actual investment of projects is more than 2 million yuan. In addition to the project funds, it is difficult to measure the input of personnel and other elements because of their complexity [1].

\section{Project Output Analysis}

One of the main results of the project is the development of products or software system which can be tested by qualified agencies, in accordance with the relevant standards, good customer evaluation [2]. According to Table 4, more than $80 \%$ of the major industries, key industrial and institutional cooperation projects have a product output. There are a few items of software output, but both key industrial projects and key social development projects are relatively higher, more than $10 \%$.

Table 4 Project product and software output

\begin{tabular}{|c|c|c|c|c|}
\hline \multirow{2}{*}{ Item Type } & \multicolumn{2}{|c|}{ The Product Through the Test } & \multicolumn{2}{c|}{ The Software Through the Test } \\
\cline { 2 - 5 } & Number of Items & Percent & Number of Items & Percent \\
\hline A1 & 20 & $90.9 \%$ & 1 & $4.5 \%$ \\
\hline A2 & 144 & $81.8 \%$ & 22 & $12.5 \%$ \\
\hline A3 & 9 & $14.1 \%$ & 0 & $0.0 \%$ \\
\hline A4 & 5 & $11.1 \%$ & 5 & $11.1 \%$ \\
\hline A5 & 2 & $22.2 \%$ & 0 & $0.0 \%$ \\
\hline A6 & 1 & $3.7 \%$ & 0 & $0.0 \%$ \\
\hline B1 & 1 & $25.0 \%$ & 0 & $0.0 \%$ \\
\hline B2 & 78 & $89.7 \%$ & 4 & $4.6 \%$ \\
\hline B3 & 3 & $8.1 \%$ & 1 & $2.7 \%$ \\
\hline B4 & 28 & $29.2 \%$ & 5 & $5.2 \%$ \\
\hline C & 1 & $4.8 \%$ & 1 & $4.8 \%$ \\
\hline Total & 292 & & 39 & \\
\hline
\end{tabular}

Table 5 Published paper

\begin{tabular}{|c|c|c|c|c|}
\hline \multirow{2}{*}{ Item Type } & \multicolumn{2}{|c|}{ Ordinary Articles } & \multicolumn{2}{c|}{ SCI, EI or Core Journals Articles } \\
\cline { 2 - 5 } & $\begin{array}{c}\text { Total } \\
\text { Number }\end{array}$ & $\begin{array}{c}\text { The Number by } \\
\text { Average Project }\end{array}$ & $\begin{array}{c}\text { Total } \\
\text { Number }\end{array}$ & $\begin{array}{c}\text { The Number by } \\
\text { Average Project }\end{array}$ \\
\hline A1 & 14 & 0.64 & 0 & 0.00 \\
\hline A2 & 71 & 0.40 & 28 & 0.16 \\
\hline A3 & 42 & 0.66 & 5 & 0.08 \\
\hline A4 & 41 & 0.91 & 26 & 0.58 \\
\hline A5 & 1 & 0.11 & 1 & 0.11 \\
\hline A6 & 26 & 0.96 & 7 & 0.26 \\
\hline B1 & 0 & 0.00 & 0 & 0.00 \\
\hline B2 & 38 & 0.44 & 1 & 0.01 \\
\hline B3 & 7 & 0.19 & 4 & 0.11 \\
\hline B4 & 114 & 1.19 & 39 & 0.41 \\
\hline C & 160 & 7.62 & 68 & 3.24 \\
\hline Total & 514 & 0.87 & 179 & 0.29 \\
\hline
\end{tabular}

The research results of the science and technology projects is published by the paper, the number of which is also one of the important indicators to measure the output of the project [3]. According to Table 5, the type of project published the largest number of paper by average is public platform project, the average public platform project to produce 7.62 ordinary articles, 3.24 SCI, EI or core 
journals articles. Public service application technology projects, key or general agricultural projects published more articles than others by average, because these project usually are performed by the university, research institutes and hospitals, which have attached great importance to the publication of papers [4].

The number of patents is an important symbol to measure the innovative achievement of the science and technology projects, especially the number of invention patents [5]. According to Table 6 , from the projects have been authorized invention patent, public platform has more authorized invention patents by average project ( 0.67 invention patents per project). The major industrial projects have more authorized utility model patent ( 1 patents utility model patent per project), followed by key industrial and public platform projects (0.8-0.9 utility model patent per project). From the application but unauthorized patent number, the number of public platform project is the most by average project, followed by major industry project, institute and university cooperation projects and key industry project.

Table 6 Patent application and authorization

\begin{tabular}{|c|c|c|c|c|c|c|}
\hline \multirow{2}{*}{ Item Type } & \multicolumn{2}{|c|}{$\begin{array}{c}\text { Patent Application } \\
\text { (Unauthorized ) }\end{array}$} & \multicolumn{2}{c|}{$\begin{array}{c}\text { Authorized Invention } \\
\text { Patents }\end{array}$} & \multicolumn{2}{c|}{ Utility Model Patent } \\
\cline { 2 - 7 } & Num. & Num. by Aver. & Num. & Num. by Aver. & Num. & Num. by Aver. \\
\hline A1 & 21 & 0.95 & 9 & 0.41 & 22 & 1.00 \\
\hline A2 & 112 & 0.64 & 30 & 0.17 & 156 & 0.89 \\
\hline A3 & 11 & 0.17 & 3 & 0.05 & 5 & 0.08 \\
\hline A4 & 4 & 0.09 & 7 & 0.16 & 1 & 0.02 \\
\hline A5 & 2 & 0.22 & 0 & 0.00 & 0 & 0.00 \\
\hline A6 & 0 & 0.00 & 1 & 0.04 & 0 & 0.00 \\
\hline B1 & 0 & 0.00 & 0 & 0.00 & 0 & 0.00 \\
\hline B2 & 58 & 0.67 & 16 & 0.18 & 70 & 0.80 \\
\hline B3 & 0 & 0.00 & 3 & 0.08 & 0 & 0.00 \\
\hline B4 & 40 & 0.42 & 14 & 0.15 & 23 & 0.24 \\
\hline C & 47 & 2.24 & 14 & 0.67 & 17 & 0.81 \\
\hline Total & 295 & & 97 & & 294 & \\
\hline
\end{tabular}

Table 7 Project economic benefit

\begin{tabular}{c|c|c|c|c|c|c}
\hline \multirow{2}{*}{ Item Type } & \multicolumn{2}{|c|}{ Sales } & \multicolumn{2}{c|}{ Profit } & \multicolumn{2}{c}{ Tax } \\
\cline { 2 - 7 } & Total & Aver.by Item & Total & $\begin{array}{c}\text { Aver.by } \\
\text { Item }\end{array}$ & Total & Aver.by Item \\
\hline A1 & 11499.9 & 1045.4 & 1583.7 & 144.0 & 767.1 & 69.7 \\
\hline A2 & 153340.9 & 1226.7 & 18805.6 & 154.1 & 7701.5 & 64.2 \\
\hline A3 & 4812.6 & 320.8 & 587.7 & 45.2 & 146.8 & 29.4 \\
\hline A4 & 2792.8 & 930.9 & 1347.0 & 449.0 & 92.4 & 46.2 \\
\hline A5 & 806.0 & 161.2 & 149.4 & 37.4 & & \\
\hline A6 & & & & & & \\
\hline B1 & & & & & 270.3 & 270.3 \\
\hline B2 & 59382.7 & 813.5 & 7340.1 & 100.5 & 3528.2 & 49.7 \\
\hline B3 & 7081.9 & 505.9 & 905.1 & 64.7 & 162.9 & 40.7 \\
\hline B4 & 2485.6 & 276.2 & 93.9 & 10.4 & 67.2 & 9.6 \\
\hline C & 455.9 & 228.0 & & & & \\
\hline Total & 242658.3 & & 30812.5 & & 12736.4 & \\
\hline
\end{tabular}

Unit: 0.01 million Yuan

The economic benefit of the project is also an important basis to evaluate the performance of the project [6]. According to Table 7, see the sales generated from the project, besides general social development projects and popularized programs of science and technology achievement did not 
produce sales revenue (or did not provide data), other types of projects have sales revenue. The most average sales revenue of the project is the key industrial projects, reaching 12.267 million yuan, the average sales of the major industrial projects is also more than 10 million yuan. The most average profit of the project is key social development projects, reaching 4.49 million yuan. The major industries, key industries institute and university cooperation projects have respectively more than 1 million yuan. The most generated tax project is popularized programs of science and technology to reach 2.703 million yuan (by a project generated).

\section{Conclusion}

This paper mainly discusses the situation of science and technology project in Shaoxing city during the 12th Five-Year Plan period by using input-output analysis and conclusions are as follow. First of all, the main reasons for the failure of the project are Lack of project investment funds, Lack of the economic benefits and Lack of the technical indicators. Secondly, the paper introduces the type of project, consisting of three major types of "first-level plan project" and 11 sub-categories of "second-level plan project". Science and technology projects mainly distributed in key industrial projects, public service application technology projects, institute and university cooperation projects. Further, the average proportion of government financial aid in the project investment is $12.73 \%$ and the effect of financial capital promoting the project actual investment is obvious. Finally, these projects to achieve higher performance mainly reflected in the following aspects: the qualified products or software system produced, the research paper published, the number of invention patents or utility model patent authorized and the economic benefit of the project.

\section{References}

[1] B. M. Werner, W. E. Souder: Research-Technology Management, Vol.40 (1997) No.2, p.34-42.

[2] P. Mohnen, B. H. Hall: Eurasian Business Review, Vol.3 (2013) No.1, p.47-65.

[3] J. Bell: Doing Your Research Project: A Guide for First-time Researchers (McGraw-Hill Education, UK 2014).

[4] D. M.Mertens: Research and evaluation in education and psychology: Integrating diversity with quantitative, qualitative, and mixed methods (Sage publications, 2014).

[5] P. Aghion, P. Howitt and S. Prantl: Journal of Economic Growth, Vol.20 (2015) No.3, p. 223-262.

[6] S. A. Marglin: Public Investment Criteria (Routledge Revivals): Benefit-Cost Analysis for Planned Economic Growth (Routledge, 2014). 